\title{
Rejim Güvenliği ve Tunus Dış Politikası
}

\author{
Selim Dursun*
}

\section{Öz}

$\mathrm{Bu}$ çalı̧̧a rejim güvenliği ve Tunus dış politikası arasındaki ilişki hakkındadır. Devletlerin dış politika davranışlarının açıklanmasında devlet düzeyindeki yaklaşımlar, dış politika davranışlarını iç değişkenlerle açıklama iddiasındadır. Devlet düzeyindeki yaklaşımlardan birisi de rejim güvenliğinin dış politikaya etkisi üzerinedir. Bu yaklaşıma göre devletler, rejim güvenliğine yönelik tehditleri birincil tehdit olarak algılar ve dış politika enstrümanlarını kullanarak bu tehditleri dengelemeye çalışırlar. Çalışma bu argümanı sınamak için Tunus dış politikası örnek olayını kullanmaktadır. Örnek olayda Tunus rejiminin yapısı ve işleyişi, rejim güvenliğine tehdit olarak algılanan Tunus İslami hareketinin gelişimi ve dış politika davranışları mevcut verilerle incelenmektedir. Çalışma, örnek olayın Tunus dış politikası yapımı üzerinde rejim güvenliğinin etkili olduğu öngörüsünü doğruladığı sonucuna ulaşmaktadır.

Anahtar Kelimeler: Rejim Güvenliği, İç Tehditler, Dış Politika, Tunus İslami Hareketi, Tunus Dış Politikası

Dr. Öğrencisi, Sakarya Üniversitesi Sosyal Bilimler Enstitüsü Uluslararası İlişkiler Bölümü, selimdursun2000@hotmail.com 


\title{
Regime Security and Tunisian Foreign Policy
}

\author{
Selim Dursun*
}

\begin{abstract}
This study is about the relationship between regime security and Tunisian foreign policy. State-level approaches to explaining foreign policy behavior of states claim to explain foreign policy behavior with internal variables. One of the approaches at the state level is about the effect of regime security on foreign policy. According to this approach, states perceive the threats to regime security as the primary threat and try to balance these threats with foreign policy instruments. The study uses Tunisian foreign policy case study to test this argument. In case study, the structure and operation of the Tunisian regime, the development of the Tunisian Islamic movement, perceived as a threat to regime security, and foreign policy behaviors are examined. The study concludes that the case confirms that regime security is effective on Tunisia's foreign policy making.
\end{abstract}

Keywords: Regime Security, Internal Threats, Foreign Policy, Tunisian Islamic Movement, Tunisian Foreign Policy

* PhD Student, Sakarya University, Institute of Social Science, International Relations, selimdursun2000@hotmail.com 


\section{Giriş}

Devletlerin dış politika davranışları üzerinde etkili olan nedenlerin ne ya da neler olduğu üzerinde literatürde çok sayıda yaklaşım ve çalışma bulunmaktadır. Sistemik yaklaşımlar baskın olmakla birlikte devlet düzeyindeki yaklaşımlar da devletlerin dış politika davranışlarını iç değişkenlerle açıklama iddiasındadır. Devlet düzeyindeki yaklaşımlardan birisi de rejim güvenliği ve diş politika ilişkisi üzerinedir. Bu yaklaşıma göre devletler rejim güvenliğine yönelik tehditleri birincil tehdit olarak algılarlar ve diş politika enstrümanlarını kullanarak bu tehditleri dengelemeye çalışırlar.

Rejim güvenliğine yönelik iç tehditler genellikle Üçüncü Dünya olarak bilinen zayıf ve küçük devletlerde daha fazla görülebilmektedir. Bu devletlerde rejimin meşruiyeti genellikle zayıf olduğundan, rejimler iç tehditlerle daha fazla yüzleşirler. Rejim güvenliğine yönelik iç tehditler çeşitli şekillerde ortaya çıkabilmektedir. Bu tehditlerin büyük çoğunluğu darbeler, şiddetli gösteriler, halk ayaklanmaları ve isyanlar şeklinde ortaya çıkabilmektedir.

Çalışmanın birinci kısmında, rejim güvenliği ve dış politika ilişkisi üzerindeki literatür değerlendirmesi yapılacaktır. Çalışmanın ikinci ve üçüncü kısmında, rejim güvenliği meselesinin dış politika davranışını etkilediği argümanı örnek olay incelemesi metoduyla sınanacaktır. Bunun için Tunus rejiminin yapısı ve işleyişi, rejim güvenliğine tehdit olarak algılanan Tunus İslami hareketinin gelişimi ve dış politika davranışları mevcut verilerle incelenecektir. Sonuç bölümünde ise örnek olay incelemesini, rejim veya iktidar değişimlerine göre üç döneme ayırarak, rejim güvenliğine yönelik tehditler ortaya çıktığında, bu tehditlerin dış politikaya etkisinin olup olmadığı, olduysa bunun nasıl olduğuyla ilgili analizlere yer verilecektir.

\section{Rejim Güvenliği ve Dış Politika}

Rejim güvenliği meselesi ülkelerin dış politika davranışlarının temelinde yer alabilmektedir. Dış politika, devletlerin dış güvenlik değerlendirmelerinin yanı sıra, rejimin iktidarı sürdürme ve hayatta kalma stratejilerine göre de şekillenmektedir. Rejim güvenliği sorunu daha çok iktidar değişimlerinin normal anayasal veya kurallı bir şekilde yapılmadığı/yapılamadığı ülkelerde ortaya çıkmaktadır. Bu durumdaki ülkelerde iktidardaki rejimler genellikle meşruiyet sorunlarıyla karşılaşır ve iktidar ya da rejim değişikliği yönünde toplumda güçlü talepler ortaya çıkar. İktidardaki rejim 
ise bu taleplere karşı iktidarını sürdürebilmek ve iç talepleri veya tehditleri dengelemek için dış politika stratejileri üretirler.

Rejim güvenliği ve dış politika arasındaki ilişkinin nasıl işlediğiyle ilgili birçok yaklaşım bulunmaktadır. Steven R. David'in her şeyi dengeleme teorisine göre, Üçüncü Dünya devletlerinin ittifak davranışları liderlerin ve rejimlerin yüzleştiği iç tehditler ve bu tehditlerden kaynaklanan hayatta kalma sorunları görmezden gelinerek açıklanamaz. Üçüncü Dünya liderleri ikincil düşmanları yatıştırarak, iktidarda ve hayatta kalmak için birincil iç ve dış tehditlerin her ikisine karşı dengeleme yaparlar. David, bir dış politika davranışı olan ittifakların temelinde Üçüncü Dünya liderlerinin ve rejimlerinin hayatta kalma kaygısının olduğunu söyler. Çünkü bu devletlerde liderlerin veya rejimlerin iktidarına ve hayatta kalmasına yönelik iç tehditler diğer devletlerden gelen tehditlerden daha çoktur. Liderler de anlaşılır şekilde en yakın ve birincil olan tehditlere karşı koymak amacıyla daha az tehdit doğuran diğer devletleri yatıştırırlar. Bu sayede iç rakiplerinin uluslararası ittifaklarını yatıştırmış olurlar ve enerjilerini en tehlikeli iç rakiplerine odaklama imkanı bulurlar. Bu davranış görünüşte ikincil tehdit oluşturan devlet ya da devletlerin peşinden gitme gibi görünür, ancak bu en önemli ve yakın düşmanla savaşmak için gücünü koruma ve düşmanı dengeleme politikasıdır. ${ }^{1}$

Michael N. Barnett ve Jack S. Levy, Üçüncü Dünya ülkelerinin ittifak davranışlarını iç istikrar ve iç ekonomi politik tercihleri dikkate alan bir yaklaşımla açıkladılar. Onlara göre güvenlik sağlamada dış ittifak kurma ile dengeleme ve iç kaynaklarla dengeleme arasında bir değiş-tokuş vardır. İç tehditlerin varlığı ve materyal kaynakları iç tehditlere karşı kullanma gereksinimi nedeniyle liderler veya rejimler dış ittifaka yönelerek dış kaynak desteği sağlayabilirler. Dış tehdit ortaya çıktı̆̆ zaman yetersiz iç kaynakların dış tehditlere karşı kullanılması durumunda ise toplum refahı azalacağından toplumsal huzursuzlukların ortaya çıkmasına ve rejim güvenliğinin tehlikeye girmesine sebep olabilir. Bu nedenle liderler rejime yönelen iç tehditlere karşı kullanılabilecek kaynakları güvenceye alabilmek ve israf etmemek için dış ittifak arayışına girebilirler. ${ }^{2}$ Richard J. Harknett ve Jeff-

Steven R. David, “Explaining Third World Alignment," World Politics, 1991, Cilt 43, No 2, s. 235-239.

2 Michael N. Barnett ve Jack S. Levy, "Domestic Sources of Alliances and Alignments: The Case of Egypt, 1962-73" International Organization, 1991, Cilt 45, No 3, s. 369376. 
rey A. Vandenberg de devletlerin ittifak davranışlarının dış tehditlerden ziyade rejime iç tehditler tarafindan yönlendirildiğini savunurlar. Onlara göre, bir devlet rejimine yönelen yakın bir iç tehdidi dengelemek için uzun bir süre tehdit oluşturan bir dış güçle ittifak yapabilir. Onlara göre bu durumda ittifakların temel belirleyeni bir rejime karşı tehdidin yoğunluğudur. Belirli koşullarda bir liderin bireysel hayatta kalma endişesi bile dış ittifak davranışını motive edebilir. Liderler bazen uzun dönem devlet çıkarları pahasına kendilerini korumaya çalışılar. Bu açıklamalar güvenlik ittifaklarının belirli bir rejimin yüzleştiği en yakın ve önemli tehdide bir tepkinin sonucu olduğu varsayımına dayanmaktadır. Devletler en yakın ve birincil olabilen bu iç tehditleri dengelemek için veya onu yatıştırmak için uluslararası ittifak arayışına girebilirler. Çoğu Üçüncü Dünya ve Sovyetler Birliği’nin yıkılmasından sonra ortaya çıkan devletlerde iç tehditlerden kaynaklanan ittifak davranışları görülebilmektedir. ${ }^{3}$

Belirli iç tehditlerle yüzleşen liderler ve elitler, dış politikada ulusal çıkarlardan ziyade rejimin hayatta kalmasına yönelik çabaların içine girebilirler. Curtis R. Ryan'a göre dış politikada ittifaklar veya işbirlikleri, yönetici siyasi elitin kendi güvenliklerini sağlamak ve hayatta kalmayı sürdürebilmek amacıyla yapılabilmektedir. Devletler rejim güvenliği açısından tanımlanan dar çıkarlara göre dış ittifak ve işbirliği yapabilirler. Burada temel çıkar ulusal çıkar değildir, elitlerin kendi güvenlik ve hayatta kalmalarına yönelik özel çıkarlardır. Bu çıkarların yönlendirdiği amaç, iktidardaki rejimin sürdürülmesine yönelen tehditleri engellemeyi başarmaktır. Bu bakımdan iç tehditlerden dolayı, iç politikada daha çok sınırlamalara maruz kalan devletler daha çok dış ittifaklara yönelebilirler. Ryan'a göre, otoriter rejimlerle yönetilen devletler, rejime yönelik iç destek az olduğundan, bu rejimler daha çok dış destek arayışına girebilirler. Dolayısıyla bu rejimler dış ittifaklar yoluyla iktidar koalisyonları kurabilirler. Ona göre çoğu Arap rejimleri iktidarlarını güçlendirmek için iç destekten ziyade, dış ittifaklara dayanma politikası izlemiştir. ${ }^{4}$

Richard J. Harknett ve Jeffrey A. Vandenberg, "Alingment Theory and Interrelated Therats: Jordan and the Persian Gulf Crisis", Security Studies, 1997, Cilt 6, No 3, s. 113-125.

4 Curtis R. Ryan, Regime Security and Jordanian Foreign Policy, Gainesville: University Press of Florida 2009, s. 12-17. 
İç tehditler devletleri belirli bir dış politika davranışına zorladığı gibi, aynı zamanda dış tehditleri dengeleme çabalarında etkinliği zayıflatabilir. Randall L. Schweller bu durumu yetersiz dengeleme kavramıyla açılar. Ona göre sosyal bölünme, hükümet veya rejim kırılganlığı, elit bölünmüsslüğü ve tehdide nasıl cevap verileceği konusunda elit uyuşmazlığg gibi iç uyumsuzlukla yüzleşen devletler, bir dış tehdide muhatap olduklarında o tehdidi yeterli bir şekilde dengeleyemezler. Örneğin rejim kırılganlığı sorunu ile muhatap olan devletlerdeki liderler diğer devletlerdeki liderlere göre, tehdidi dengelemek için iç kaynaklardan faydalanma imkânı noktasında daha çok sınırlandırılmıştır. Meşruiyet bakımından zayıf liderler diğer liderlere göre daha az siyasi kapasiteye sahip olur. Zayıf meşruiyet iç kaynakları bitirebilir. Rejim, muhalifleri yatıştırma, onları kendi saflarına kazanma veya hayatta kalma çabası içine girebilir. Bu durum kıt ulusal kaynakların tükenmesine yol açabilir. Ancak diş ittifak, bir tehdidi dengelemede göreceli olarak daha az maliyet yükler. Bu nedenle zayıf rejimlerin tehdide karşı koymak için savunma harcaması yapmak yerine, dış ittifak arayışı içine girmeleri daha muhtemeldir. ${ }^{5}$

Rejim güvenliğine yönelik iç tehditler çeşitli görünümler alabilmektedir. David'e göre Üçüncü Dünya devletlerinin çok azı dış işgale maruz kalmıştır. Ancak, bu devlet liderlerinin yüzlercesi onların iç düşmanları tarafindan devrilmiştir. Bu devletlerdeki rejim değişikliklerinin çoğu darbeler yoluyla gerçekleşmektedir ve bu şekilde birçok rejim değişikliği meydana gelmiştir. ${ }^{6}$ Jackson, zayıf devletlerin sahip olduğu yapısal özelliklerin zora dayalı uyum, hükümet krizleri, darbeler, ayaklanmalar ve isyanlar gibi istikrarsızlıklar ürettiğini savunur. ${ }^{7}$ Rejimler ayrıca sert ve dinamik muhalefet hareketleriyle de karşılaşabilirler. Bu durumla karşılaşan liderler rejim değişikliğinden endişelenirler. ${ }^{8}$ Rejim güvenliğine yönelik iç tehditler ve bu tehditlerin ortaya çıkış şekli, devletlerin dış politikada kendilerinden

Randall L. Schweller, "Unanswered Threats: A Neoclassical Realist Theory of Underbalancing”, International Security, 2004, Cilt 29, No 2, s. 170-175.

David, s. 238-239.

Richard Jackson, "Violent Internal Conflict and the African State: Towards a Framework of Analysis", Journal of Contemporary African Studies, 2002, Cilt 20, No.1, s. 38-39.

$8 \quad$ Eric A. Miller ve Arkady Toritsyn, "Bringing the Leader Back In: Internal Threats and Alignment Theory in the Commonwealth of Independent States", Security Studies, 2005, Cilt 14, No 2, s. 334-335. 
beklenmeyen ya da güç dağılımına uygun olmayan davranışlar göstermelerine neden olabilmektedir. Bu öngörüler 1956-2016 dönemi Tunus dış politikası örnek olayı ile sınanacaktır. Örnek olayda Tunus rejiminin yapısı ve işleyişi, rejimin tehdit olarak algıladığı Tunus İslami hareketinin gelişimi ile dış politika davranışları incelenecektir. Bu şekilde rejim güvenliğine yönelik tehditlerin dış politika yapımı üzerinde etkisi hakkında değerlendirme imkânı elde edilmiş olacaktır.

\section{Tunus Rejimi ve Rejim Güvenliğine Yönelik Tehditler}

\subsection{Tunus Rejiminin Yapısı ve İşleyişi}

Tunus'un bağımsızlık süreci, aynı zamanda yeni rejimin yapısını oluşturan şartları da hazırladı. Tunus, Habib Burgiba'nın 1934 yılında başlattığı Yeni Düstur Partisi hareketi etrafinda Fransa'ya karşı bağımsızlık mücadelesi yürüttü. Bu mücadele sonrasında Tunus, 1956 yılında Fransa ile imzalad1ğ bir anlaşmayla bağımsız bir devlet oldu. Ancak bu süreçte Yeni Düstur Partisi içinde Burgiba'nın Fransa ile yürüttüğü bağımsızlık müzakerelerine ve bu süreçte imzalanan anlaşmalara karşı çıkan ve liderliğini Salih bin Yusuf'un yaptığı muhalif bir gurup ortaya çıtı. Bin Yusuf, Tunus'un tam bağımsızlı̆̆ını, Kuzey Afrika' daki Arap milliyetçileriyle işbirliği yapılmasinı ve Fransa ile askeri mücadeleyi savunuyordu. Bin Yusuf ayrıca Arap ve geleneksel İslami kültüre daha çok uyuşan bir kimliği temsil ediyordu. Burgiba ise Arap milliyetçiliği yerine seküler, Batı yönlü modern bir devlet kurma ve Fransa ile ilişkilerin sürdürülmesi taraftarıydı. Bin Yusuf hem Burgiba hem de Fransa yönetimine karşı direniş gruplarıyla askeri ve sivil mücadele yürüttü. Ancak Burgiba, Salih bin Yusuf önderliğindeki milliyetçi kesimleri tasfiye etmeyi başardı. Bu sürecin ardından Burgiba, Fransa ile bağımsızlık müzakeresine devam etti ve 20 Mart 1956 tarihinde Fransa ile Tunus'un bağımsızlığını ilan eden anlaşma imzaladı. ${ }^{9}$ Burgiba'nın hem bağımsızlığın kazanılmasında hem de parti içindeki muhalefeti tasfiye etmesindeki başarısı, ona fikirleri doğrultusunda yeni bir rejim kurma imkânı verdi.

Veysel Ayhan, “Tunus İsyanı: Arapların Devrim Ateşini Yakması”, Ortadoğu Etütleri, 2012, Cilt 3, No 2, s. 59-93; Christopher Alexander, Tunisia: Stability and Reform in the Modern Maghreb, London: Routledge 2016, s. 28-31. 
Tunus'un ilk başkanı Burgiba, Tunus'un Fransız sömürgesi altında olduğu dönemde Fransa'da eğitim almış, seküler ve reformcu görüşleri benimsemiş bir liderdi. O, Batı yanlısı ve özellikle Fransız değerlerini ve kurumlarını model alan seküler ve modern bir devlet ve toplum oluşturmayı hedefledi. Burgiba ve elitinin tasavvur ettiği modernizm batılılaşmayla eş anlamlıydı. Bu dönemde rejimin temel sloganı gelişmiş ülkelere yetişmekti. Onlar gelişmiş ülkelerin en iyi örneği olarak Fransa'yı görüyordu. ${ }^{10}$ Burgiba, Batı yanlısı modernleşmeyi "modern dünyanın bir parçası olarak yaşamak", "gerçekle yüzleşebilmek için diğer kültürlere, özellikle Batı kültürüne pencereleri açmak" şeklinde ifade etti. ${ }^{11}$ Medeniyet tercihini Batıc1lık yönünde yapan Burgiba, diğer yandan komünizm ve Pan-Arabizm gibi ideolojileri reddetti. ${ }^{12}$ Tunus modernleşmesi, Batıcılık yanında laiklik ilkesine de dayanıyordu. Fransız laikliğini model alan Burgiba, modernleşme ve toplumu dönüştürme hedeflerini bu ilkeyle gerçekleştirmeye çalıştı.

Burgiba, hedeflerini gerçekleştirmek ve yeni devletin ilkelerini hayata geçirmek amacıyla tek parti egemenliğine dayalı otoriter yönetim rejimi kurdu. Yeni Düstur Partisi, ülkeyi bağımsızlığa taşıdığı için halkın büyük desteğine ve tüm ülkeye yayılan güçlü bir örgütsel yapıya sahipti. Burgiba, bağımsızlık mücadelesinin kahramanı olarak görüldügünden parti içinde pozisyonunu güçlendirdi ve partideki muhtemel rakiplerinin gücünü zayıflattı. Burgiba, 1960'lı yılların başında Tunus siyasal sistemi hakkındaki bir soruya verdiği yanıtta bu durumu kabul etti: "Sistem? Hangi sistem? Ben sistemim". ${ }^{13}$ Burgiba döneminde bir dönem başbakanlık yapan Hadi Nouria'nın tek parti yönetimi hakkındaki değerlendirmesi rejimin yapısını ortaya koymaktadır:

10 Yeni rejimin oluşumunda Burgiba'nın fikirleri ve hedeflerinin etkisi hakkında ayrıca bkz. John L. Esposito, Tamara Sonn ve John O. Voll, Islam and Democracy after the Arab Spring, Oxford: Oxford University Press 2016, 176-177; Kenneth Perkins, "Playing the Islamic Card: The Use and Abuse of Religion in Tunisian Politics", The Making of the Tunisian Revolution: Contexts, Architects, Prospects, Nouri Gana (ed.), Edinburgh: Edinburgh University Press 2013, s. 59-63; Alexander, Tunisia: Stability and Reform in the Modern Maghreb, s. 35; Raşid Gannuşi, Laiklik ve Sivil Toplum, İstanbul: Mana Yayınları 2015, s. 122.

11 H. Rumeysa Dursun, "Tunus’ta Otoriter Yönetim ve İslamcı Hareketin Doğuşu: Burgiba Dönemi Üzerine Bir Değerlendirme (1956-1987)”, Türkiye Ortadoğu Çalışmaları Dergisi, 2017, Cilt 4, Sayı 1, s. 137.

12 Alexander, s.63-64.

13 Alexander, s.63-64. 
"Bizim politik toplumun dominant özelliği parti ve devletin bölünmez karakteridir. Bizim siyasi sistemimiz temel olarak parti etrafinda döner. Parti, egemen ideolojinin oluşturucusu, devlet ve kitlelerin organizatörü, organize olmuş gücün enstrümanıdır. Politika tasarlama ve formüle etmede parti devlet ilişkisi kurumlarımıza ve yapılarımıza taşınmalıdır". ${ }^{14}$

$\mathrm{Bu}$ temel fikirlerle ve araçlarla bağımsızlığın ilk yıllarında başlatılan reformlar, toplumsal hayatta ve yönetimde egemen olan İslam dini ve Arap kültür kurumlarını hedef aldı. Rejim ilk olarak dini kurumları kontrolü altına almaya çalıştı. İslami eğitim kurumları ortadan kaldırılarak seküler eğitim sistemi benimsendi. Yarg1 alanında geleneksel İslam hukuku uygulamaları kaldırıldı. Rejimin bu reformlardaki amacı dini pratikleri devlet ve toplum hayatından çıkarmaktı. ${ }^{15} \mathrm{Bu}$ çerçevede rejim Kur'an okullarını, camileri ve diğer dini kurumları destekleyen vakıf gelirlerine el koydu ve vakıfları devletleştirdi. Hanefi ve Maliki şeriat mahkemelerini kaldırdı ve yarg1 sistemini merkezileştirdi. Ayrıca Tunus'ta dini düşüncenin ve örgütlenmenin en önemli merkezi olan Zeytune Üniversitesi'nin özerkliği kaldırıldı ve eğitim bakanlığına bağlandı. ${ }^{16}$

Sosyal alanda yapılan reformların en önemlisi yeni Medeni Kanunun kabul edilmesi oldu. Bağımsızlığın ilk yılında kabul edilen Medeni Kanun'la çok eşlilik yasaklandı, kız çocuklarının evlenme yaşına alt sınır getirildi, kadınlara boşanma hakkı tanındı ve erkeklerin boşanma hakkıyla ilgili sınırlamalar getirildi. ${ }^{17}$ Dini ve sosyal alanda yapılan modernleşme ve laiklik uygulamaları söylem düzeyinde de kendisini gösterdi. Burgiba yaptığ konuşmalarda kadınların geleneksel kıyafetlerini eleştirdi. Ona göre bu kıyafetler kadınların modern topluma aktif bir şekilde katılmalarına engel olmaktayd $1 .{ }^{18}$ Burgiba ayrıca Ramazan orucunu eleştirdi ve az gelişmiş̧likle mücadele etmek için orucunun tutulmaması gerektiğini savundu. ${ }^{19}$ Burgiba, geleneksel ve İslami yapıları eylem ve söylem düzeyinde modernizm ve ilerlemenin karşıtı olarak konumlandırdı. Tunus rejiminin işlevi

\footnotetext{
14 Alexander, s.42.

15 Esposito, Sonn ve Voll, s. 176-177.

16 Perkins, "Playing the Islamic Card: The Use and Abuse of Religion in Tunisian Politics", s. 61; Rory McCarthy, "Re-thinking secularism in post-independence Tunisia" Journal of North African Studies, 2014, Cilt 9, No 5, s. 735-736.

17 McCarthy, s.736.

18 Dursun, s.138.

19 McCarthy, s.737.
} 
burada ortaya çıkmaktaydı: Devlet aygitlarını kullanarak Tunus toplumunu geleneksel ve İslami yapılardan arındırmak ve Batılı anlamda modernleştirmek.

Rejimin yapısı ve işleyişi 1987 yılında iktidara gelen Zeynel Abidin Bin Ali döneminde de değişmedi. Burgiba'yı kansız bir darbeyle deviren Bin Ali, rejim değiş̧ikliğinden ziyade rejimi güçlendirme politikası izledi. O, rejimi güçlendirmek için ulusal konsensüs yaratmaya çalıştı. Bu konsensüsün inşasında Burgibaizm ağırlıkla temsil edildi ve harç olarak kullanıld1.$^{20}$ Bin Ali, rejimi güçlendirmek ve meşruiyetini artırmak için çok partili seçimlere izin verme, ömür boyu başkanlık kuralını kaldırmak gibi siyasi liberalizm denemeleri yaptı. Ancak bu girişimlerden geri dönüş yapan Bin Ali, devrilene kadar otoriter ve baskıcı tek parti yönetim rejimini sürdürdü.

Aralık 2010'da ekonomik sorunlardan dolayı başlayan gösteriler, zamanla rejime yönelik halk ayaklanmasına dönüştü. 1956 yılında Burgiba tarafindan kurulan ve 1987 yılından sonra Bin Ali tarafindan devam ettirilen rejim, halk ayaklanmaları sonucu Bin Ali'nin 14 Ocak 2011'de ülkeden ayrılmasıyla sona erdi. Devrimden sonra serbest ve özgür seçimlerin yapılması, bu seçimlere dayalı iktidar değişimlerinin gerçekleşmesi ve iktidar değişimini kurala bağlayan yeni anayasanın benimsenmesi demokratik rejime geçişin önemli adımlarını oluşturdu.

\subsection{Tunus İslami Hareketinin Ortaya Çıkışı ve Rejim Güvenliği}

1960'lı yılların ortalarından itibaren rejimin yapısı ve işleyişine karşı muhalefet hareketleri ortaya çıkmaya başladı. Bu muhalefet hareketlerinin en önemlisi Tunus İslami hareketidir. Bu hareket ilk başlarda geleneksel değerleri, İslami ve Arap kimliğini koruma refleksiyle ortaya çıkmışsa da, daha sonra ekonomik ve toplumsal sorunların etkisiyle siyasal bir harekete dönüştü. İslami hareketin sosyal ve siyasal alana evrilmesi onların toplumsal bağlarını güçlendirdi ve onları rejime alternatif bir duruma getirdi.

İslami hareketin ortaya çıkmasının ve gelişmesinin iki temel nedeni vardır. Bunlardan birincisi ve en önemlisi Tunus rejiminin Batıcllık ve laiklik ekseninde işleyen modernleşme tasavvuru ve uygulamalarından kaynak-

20 Emma C. Murphy, Economic and Political Change in Tunisia: From Bourguiba to Ben Ali, London: Macmillan 1999, s. 164-167. 
lanmaktaydı. İslami hareketin kurucularından ve liderlerinden Raşid Gannuşi Tunus rejimine karşı İslami muhalefet hareketinin ortaya çıkmasının nedenini şu şekilde açıklar: "Ennahda ve dolayısıyla Tunus'taki ilk İslami hareket, vatandaşların dini özgürlüklerini, serbest ifade ve örgütlenme haklarını reddeden sekülarist, otoriter bir rejimin elindeki baskı araçlarına yanıt olarak ortaya çıktı". ${ }^{21}$ Yine Esposito, Sonn ve Voll da benzer görüştedir. Onlara göre, Burgiba Fransız değerlerini ve kurumlarını model alan seküler bir devlet ve toplum oluşturmak için başta eğitim ve hukuk alanında olmak üzere birçok alanda reformlar yaptı. Özellikle İslami eğitim kurumlarının ortadan kaldırılması ve seküler eğitim sisteminin benimsenmesi, geleneksel İslam hukuku uygulamalarının kaldırılması, İslam pratiklerinin devlet ve toplum hayatından çıkarılması çabaları Tunus'un seküler rejimine karş1 güçlü bir muhalefet hareketinin temellerinin atılmasına yol açtı. ${ }^{22}$ Marion Bouldby, İslami hareketin kökenini Tunus'un bağımsızlığını takip eden on yılda gerçekleştirilen reformlara dayandırır. Ona göre bu yıllar İslami kurumların modernleşmeci elitler tarafindan ortadan kaldırılmasına sahne oldu ve bu reformlar İslami hareketin doğuşuna neden oldu. ${ }^{23}$

İkinci neden ekonomik, sosyal ve siyasal koşullardan kaynaklandı. 1960'larda Tunus, planlı sosyalist bir ekonomi modeli uygulamıştı. Ancak uygulanan model başarısız oldu ve ekonomik sorunlara, işsizliğe ve toplumsal memnuniyetsizliğin büyümesine yol açtı. Hükümet bu memnuniyetsizliği azaltmak için siyasi ve ekonomik liberalleşme politikaları izlemeye başladı. Bu ortam Tunus'un Arap-İslam kimliğinin ve mirasının yeniden canlanmasına katkı sağladı. ${ }^{24}$ Bunun yanında ekonomik sorunlara karş1 sol gruplar ve sendikalar da reform taleplerini ve tepkilerini artırmaya başladılar. Hükümet bu hareketlere karşı anlaşmazlığa düştü ve sendikal hareketi ülkenin istikrarına tehdit olarak görmeye başladı. Hükümetin işçi sendikasına yönelik baskılarını artırması sendikanın ülkedeki etkisini azalttı. Tunus rejimi ayrıca sol guruplardan ve sendikal hareketlerden gelen muhalefet dalgasına karşı "Kuran'1 Koruma Birliği”" olarak adland1rılan bir örgütlenmeyi destekledi. Siyasi bir ajandası olmayan bu birlik,

21 Raşid Gannuşi, "From Political Islam to Muslim Democracy: The Ennahda Party and the Future of Tunisia" Foreign Affairs, September/October 2016, s. 58.

22 Esposito, Sonn ve Voll, s.176-177.

23 Marion Boulby, "The Islamic Challenge: Tunisia since Independence", Third World Quarterly, 1988, Cilt 10, No 2, s. 590-614.

24 Esposito, Sonn ve Voll, s.179. 
Tunus kimliğinin kurucu unsurları olarak Arap diline ve İslami değerlere vurgu yapıyordu. Hükümetin bu dönemde sol hareketleri yasaklaması bu gurubun özellikle üniversite kampüslerinde alan bulmasına yol açtı. Ayrıca ekonomi alanındaki başarısızlık rejimin meşruiyetini aşındırdı ve bu aşınma İslami hareketin gelişimini etkiledi. ${ }^{25}$

Bu dönemde İslami bir vizyona sahip bir aktivist olan Gannuşi'nin fikirlerine ilgi artmaya başladı. ${ }^{26}$ Gannuşi'nin fikirleri Tunus'un seküler rejimine muhalif bir hareketin doğmasına öncülük etti. Arap milliyetçiliğine mesafeli olan Gannuşi, Tunus'un sosyalist ekonomi politikalarını da eleştiriyordu. Gannuşi ayrıca geleneksel İslam kurumlarını katı ve sönük görüyordu. Ona göre "geleneksel model ideolojik değildi, o kapsayıcı bir sistemi temsil etmiyordu. Medeniyeti ve hayatın yönlerini yansıtmada yetersiz kalan geleneksel din duygular, adetler, örfler ve ritüeller setiydi". ${ }^{27}$ Gannuşi bir yandan geleneksel İslami kurumları eleştirirken, diğer yandan Batı medeniyetine karşı İslami bir alternatifi savundu. İlk dönemde ideolojik bilinçlenmenin gelişmesine odakland. Gannuşi'nin fikirleri çoğu genç, fakir, çalışan sınıf ve üniversiteli insanları kendisine çekti. Gannuşi ve arkadaşları “Kuran'1 Koruma Birliği”" ile güçlerini birleştirdi. ${ }^{28} 1970$ 'li yılların başında Arap-İslam kimliğini koruma refleksiyle ortaya çıkan bu birlik, Tunus İslami hareketin ilk nüvesini oluşturdu.

1970'lerin sonunda yaşanan gelişmeler Tunus İslami hareketi için dönüm noktasını oluşturdu. Bu gelişmelerin en önemlisi ekonomik sorunlar nedeniyle 1973-1978 yılları arasında yaşanan işçi grevleriydi. 1978 yılında gerçekleşen genel grev sırasında hükümetin sert müdahalesi birçok kişinin ölümüne neden oldu. İkinci gelişme 1979 yılında gerçekleşen İran devrimidir. Devrim İslam coğrafyasındaki İslami hareketleri etkilemeye başlad1. Hükümetin grevlere karşı sert tutumu ve İran'da gerçekleşen devrim Tunus'taki İslami aktörlerin toplumsal ve siyasal sorunlara daha çok önem vermelerine yol açt. ${ }^{29}$ Tunus İslami hareketinin liderlerinden Gannuşi bu

Alexander, s.34-47; Boulby, s.590-614 s. 34-47; Boulby, s. 590-614.

26 Gannuşi, bu dönemde reformist birçok İslamcı düşünürden özellikle de Müslüman Kardeşlerin kurucusu Misırlı Hasan el-Benna ve Suriye'deki düşünürlerden etkilendiklerini söyler. Bkz: Gannuşi, Alexander, s.34-47; Boulby, s.590-614, s. 60.

27 Esposito, Sonn ve Voll, s.177-179.

28 Ibid., s. 180.

29 Dursun, s.140-142. 
durumu şu şekilde açıklamaktadır: “. .. bu noktadan itibaren toplumsal gerçeklikler konusunda farkındalık ve duyarlılık geliştirmeye başladık. İslamcılar sendika hareketlerine katılmaya başladı". ${ }^{30}$

$\mathrm{Bu}$ gelişmeler sonrasında siyasete yönelik ilgileri artan Gannuşi’nin de içinde olduğu Kuran'1 Koruma Birliği, 1979'da siyasi bir grup olan İslam Birliği'ne dönüştü. Birlik özellikle düşük ve orta sınıf ailelerine ulaştı ve Burgiba'nın tek parti sistemini bitirmesi için çağrı yaptı. Birlik ayrıca işçi hakları, yoksulluk, ücretler, siyasi katılım gibi çağdaş problemlerin üzerine eğilen bir vizyon benimsedi. Burgiba 1981'de seçimlere diğer partilerin de katılmasına onay verdiğinde İslam Birliği siyasi bir partiye dönüştü ve İslami Yöneliş Hareketi (Islamic Tendency Movement-MTI) ismini aldı. ${ }^{31}$ Gannuşi'ye göre MTI, Burgiba rejimine muhalefet eden, özellikle dini inancından dolayı kendisini siyasi sistemden dışlanmış hisseden Tunusluları bir araya getirdi. MTI bunu tartışma gurupları kurarak, süreli yayın yaparak, üniversite kampüslerinde öğrencileri organize ederek yaptı. ${ }^{32}$ MTI ayrıca resmi parti olarak tanınma başvurusu yaptı ve şiddeti reddettiklerini, siyasi meşruiyetin tek kaynağı olarak özgür ve adil seçimleri gördüklerini ve demokratik ve çok partili siyaseti desteklediklerini taahhüt etti. ${ }^{33}$ Gannuşi’ye göre, demokrasi ve İslam birbiriyle uyumsuz değildi:

"Eğer demokrasi Batıda yaygın olan liberal hükümet modeli, halkın temsilcilerini ve liderlerini özgürce seçtiği bir sistem ve bir güç değişimi, halk için insan hakları ve özgürlüklerin varlı̆̆ anlamındaysa bu durumda Müslümanlar demokrasiye muhalif olmaları için dinlerinde hiçbir şey bulamayacaklardır ve herhangi bir şekilde böyle yapmak onların çıkarına değildir". ${ }^{34}$

İslami Yöneliş Hareketinin bu tutumuna karşın, Tunus rejimi onların güçlenmesini ve siyasileşmesini rejim güvenliğine tehdit olarak algıladı. Hareketin resmi parti olarak tanınma başvurusunu reddeden rejim, onlara karşı sert tedbirler almaya başladı. Temmuz 1981'de aralarında Gannuşi'nin de bulunduğu birçok MTI üyesi tutuklandı ve onlar illegal örgüt kurmakla

\footnotetext{
$30 \quad$ Ibid., s.143.

31 Esposito, Sonn ve Voll, s.180-181.

32 Gannuşi, s. 60-61.

33 Alexander, s. 48-49; Gannuşi, s. 61.

34 Esposito, Sonn ve Voll, s.181.
} 
suçland. ${ }^{35}$ Burgiba, İslamcıların radikal köktendinciliği desteklediğini ve İran tarzı bir dini devrimle bağlantılı olduklarını iddia ederek harekete yönelik sert tedbirleri meşrulaştırmaya çalıştı. İslami hareket üzerindeki baskıları artıran Tunus yönetimi, memurların iş sırasında namaz kılmasını, kadınların üniversitelerde ve işyerlerinde başörtüsü giymesini yasakladı. ${ }^{36}$ Ancak bu baskı ortamı ve ekonomik sorunlardan kaynaklanan hoşnutsuzluk İslami hareketin daha fazla taban bulmasına ve güçlenmesine yol açtı. İslami hareketin güçlenmesi rejim güvenliğine yönelik tehdit algısını artırd1.

İslami hareketin güçlenmesi ve toplumsal tabanını genişletmesi, Burgiba rejimini daha sert politika izlemeye sevk etti. 1984'te serbest birakılan Gannuşi 1987'de tekrar tutuklandı ve hükümete karşı darbe hazırlamak ve şiddeti kışkırtmakla suçlandı. Mahkeme Gannuşi'ye ömür boyu ağır hapis cezası verdi. Burgiba ayrıca MTI karşısında daha katı tutuma sahip içişleri bakanı Zeynel Abidin Bin Ali'yi başbakan olarak atadı. Burgiba yönetimin bu sert tutumu, İslamci hareketi rejimin siyasi gücüne rakip olarak görmesinden kaynaklandı ancak bu tutumu iktidarının da sonunu hazırladı. Bin Ali başbakan olarak atandıktan kısa bir süre sonra Burgiba'nın sağlık sorunlarını gerekçe göstererek kansız bir darbeyle 7 Kasım 1987'de Burgiba'yı iktidardan uzaklaştırdı. ${ }^{37}$

\subsection{Darbesi Sonrası Rejim Güvenliği ve İslami Hareket}

Bin Ali iktidara geldikten sonra, Burgiba'nın son dönemlerinde yıpranan rejim güvenliğini ve meşruiyetini güçlendirmeye yönelik adımlar attı. Bin Ali iktidarının ilk yıllarında siyasi liberalleşme ve anayasal reform vaatlerinde bulundu. Onun "içinde yaşadığımız çağ, halkı dışlamadan hayat boyu başkanlığa veya devlet başkanlığına otomatik halefiyete izin vermemektedir. Halkımız gerçekten siyasi partilerin ve örgütlerin çoğulculuğuna dayalı bir siyasi gelişmeyi ve örgütlenmeyi arzulamaktadır" 38 açıklaması bu yöndeki niyetini ortaya koydu. Bu kapsamda yapılan reformlarla ayn1 kişinin en fazla 15 yıl ve azami 70 yaşına kadar başkanlık yapabileceği ku-

\footnotetext{
Alexander, s.47.

Esposito, Sonn ve Voll, s.182.

Dursun, s. 151-153.

Murphy, s.167.
} 
ralı getirildi. Yine reform vaatleri kapsamında siyasi parti kurma ve faaliyet gösterme üzerindeki sınırlamalar gevşetildi ve sınırlı da olsa çok partili sisteme doğru adım atıldı. ${ }^{39}$ Bin Ali ayrıca bu dönemde önemli bir adım atarak, Burgiba'nın son döneminde tutuklanan MTI lideri Gannuşi dahil bütün siyasi mahkumları affetti ve sürgündeki muhalefet liderlerini ülkeye davet etti. ${ }^{40}$ Bin Ali'nin rejim güvenliği tesisine yönelik ikinci adımı, yeni bir ulusal konsensüs yaratmak için muhalefet partileri, ticaret ve işçi sendikaları ve İslamcı hareketin temsilcileri gibi toplumun önemli kesimlerini ulusal sözleşme dokümanı etrafında bir araya getirmesi oldu. Tartışmalar sonucunda şekillenen ve 16 farklı siyasi parti ve örgütün imzaladığı ulusal sözleşme dokümanı, Kasım 1988'de ilan edildi. Sözleşmenin en önemli yanı devletin Arap ve İslami kimliğine vurgu yapmasıydı. Söylem düzeyinde de olsa bu sözleşme, Burgiba rejiminin kapsayıcı olmayan sekülarizmi yerine, halkın İslami karakterini kabul etmeyi ve onu kapsamına dahil etmeyi amaçlad.$^{41}$ Bin Ali'nin siyasi liberalleşme vaatleri ve sınırlı da olsa yaptığg reformlar iç istikrar düzeyini artırdı ve rejim güvenliğine katk1 yapt1.

Bin Ali, iktidarının ilk yıllarında İslamcı harekete karşı dikkatli bir strateji izledi ve onlarla açıkça mücadele etmekten kaçındı. Bu stratejideki temel etken Bin Ali'nin İslami hareketin gerçek gücünden ve potansiyelinden emin olmaması ve yapılacak mücadelenin onların toplumsal desteğini daha da artıracağı endişesi taşımasıydı. ${ }^{42} \mathrm{Bu}$ dönemde İslami Yöneliş Hareketi ismini değiştirerek En-Nahda (Yeniden Doğuş-Renaissance Party) ismiyle Şubat 1989 'da meşru bir parti olarak tanınma başvurusu yaptı. Parti yetkilileri başvuru sırasında devrimci hareket olmadıklarını, demokratik siyasete bağlı reformcu bir hareket olduklarını ve devlete tehdit oluşturmadıklarını ilan etti. ${ }^{43}$ Nahda'nın legalleşme talebine olumsuz yanıt veren Bin Ali, Nisan 1989'da yapılan genel seçimlerde Nahda adaylarının bağımsız olarak seçime katılmalarına müsaade etti. Seçimde Nahda'nın bağımsız adayları ülke genelinde $\% 14$, şehirlerde $\% 30$ oy oranına uluşarak Tunus'un en büyük muhalefet partisi konumuna geldi. ${ }^{44}$ Nahda'nın bu başarısı, onun

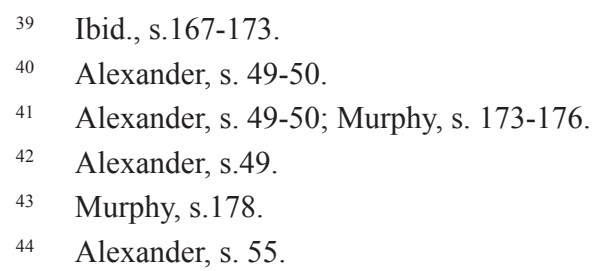


iktidar partisine karşı gerçek anlamda muhalefeti temsil ettiğini ortaya ç1kardı. Bin Ali seçim sonuçları sonrasında siyasi liberalleşme, reformlar ve İslamcılarla uzlaşma gibi adımların kendi iktidarını ve rejimine tehdit eder hale geldiğini düşünmeye başladı. ${ }^{45}$

İslami hareketin seçim başarısını ve iktidara alternatif duruma gelmesini rejim güvenliğine tehdit olarak algılayan Bin Ali, strateji değiştirerek 1990'lı yılların ortalarından itibaren Nahda'ya yönelik bask1 ve yasaklamalara başladı. Bu baskı ve yasaklama sürecinde çok sayıda Nahda aktivistleri gözaltına alındı ve tutuklandı. Bu süreçte ayrıca keyfi tutuklamalar, işkence olayları gibi insan hakları ihlalleri de yaşandı. Nahda lideri Gannuşi de seçimlerden bir ay sonra ülkeyi terk etmek zorunda kaldı. Baskıların muhatabı Gannuşi, bu gelişmeleri şu şekilde açıklamaktadır:

Bin Ali rejimi Burgiba döneminin baskıcı taktiklerine geri döndü. 1989 seçimlerinden sonra (bu seçime Nahda bağımsız adaylarla katılmışı ve $\% 13$ oranında oy almıştı. Bazı kaynaklara göre büyük şehirlerde bu oran \%30'a kadar çıkmıştı) rejim partiyi ezmeye yöneldi. Partinin on binlerce üyesi tutukland,, hapsedildi, işkencelerden geçirildi, iş ve eğitim firsatlarından mahrum birakıldı ve polis tacizlerine maruz birakıldı. Benimde içinde bulunduğum pek çoğu da sürgüne zorlandı". ${ }^{46}$

Bin Ali, 1990'lı yılların ortalarına kadar uyguladığı sert ve baskıcı tedbirlerle İslami hareketi rejimine tehdit olmaktan çıkardı. İslamcı hareketin tabanı tam olarak ortadan kaldırılamasa da, Nahda'nın Tunus'taki örgütlenmesi büyük ölçüde azaltıldı ve yeraltı hareketi olarak hayatta kalmaya zorland1. Bin Ali içerde İslami harekete ve muhalif kesimlere karşı yürüttügü sert önlemleri meşrulaştırmak için bu dönemde Cezayir iç savaşından kaynaklanan fundamentalist korkudan faydaland $1 .{ }^{47}$ Bin Ali rejiminin İslami harekete karşı sert tutumu 2000'li yıllarda da devam etti. Bin Ali'nin bu politikası özellikle 11 Eylül 2001 saldırılarından sonra ABD öncülüğünde başlatılan "terörle savaş" stratejisi kapsamında daha fazla diş destek görmeye başladı. Alınan dış destek bir yandan muhalefetin daha çok baskılanması anlamında rejim güvenliğine katkı yaparken, diğer yandan rejimin toplumsal meşruiyetini aşındırdı. Bu süreç halk ayaklanmasıyla rejimin 2011 yılının başında devrilmesine kadar sürdü.

\footnotetext{
45 Alexander, s.55. Murphy, s.180.

46 Gannuşi, s. 61.

47 Alexander, s.57-58. Gannuşi, s. 62.
} 


\subsection{Rejim Değişikliği ve İslami Hareket}

Bin Ali’nin rejim güvenliğini artırmak için içerde uyguladığı baskı, muhalefeti ve özellikle İslami hareketleri yok etme politikaları, yolsuzluklar, artan ekonomik problemler ve işsizlik rejimin sonunu getiren gelişmeler oldu. Aralık 2010'da ekonomik sorunlardan dolayı başlayan gösteriler, zamanla rejime yönelik halk ayaklanmasına dönüştü. 1956 yılında Burgiba tarafindan kurulan ve 1987 yılından sonra Bin Ali tarafindan devam ettirilen rejim, halk ayaklanması sonucu Bin Ali'nin 14 Ocak 2011'de ülkeden ayrılmasıyla sona ermiş oldu. Devrimden sonra tek parti sitemine dayalı otokratik rejimden serbest ve çok partili seçimlere dayalı demokratik rejime geçiş adımları atıldı.

Devrim sonrası yeni rejime geçişin ilk adımı, 23 Ekim 2011 tarihinde yapılan Kurucu Meclis seçimleri ile atıldı. Seçimlerde Nahda partisi oyların yüzde 41,47'sini alarak, 217 sandalyeli mecliste 90 sandalye kazand 1 ve açı ara birinci parti oldu. ${ }^{48}$ İkinci sıradaki ulusal sol eğilimli Cumhuriyetçi Kongre partisi yüzde 13,82 oy oranıyla 30 sandalye ve üçüncü sıradaki sol eğilimli Ettakatol partisi ise yüzde 9,68 oy oranıly 21 sandalye elde etti. ${ }^{49}$ Seçimlerden sonra Nahda öncülügünde ilk üç parti koalisyonuyla troyka hükümeti kuruldu. ${ }^{50}$ Demokratik rejime geçiş çabalarına rağmen, Tunus bu dönemde iç istikrasızlıklarla yüzleşti. İç istikrasızlık seküler kesimle selefilerin başını çektiği İslami guruplar arasındaki mücadeleden kaynaklandı. Seküler kesim din ve siyasetin birbirinden ayrılmasını ve kamusal alanda dinin görünür olmamasını savunuyordu. Bu tutumun karşı tarafında yer

48 Bin Ali'nin devrilmesine yol açan halk ayaklanması sırasında İslami hareket aktif bir tutum izleyemedi. Esposito, Sonn ve Voll'a göre, İslamcıların pasif kalmasının en önemli nedeni Nahda'nın uzun süre siyasetten dışlanmış olması ve örgütlenme kapasitesinin büyük oranda zarar görmüş olmasıdır. Diğer bir neden devrimin arkasındaki itici gücün İslami kaygılardan ziyade ekonomik hoşnutsuzlukların olmasıydı. Tunusluların bu süreçteki en öncelikli kaygıları ekonomik zorluklar ve işsizlikle ilgili konulardı. Ancak bu gerçeklere rağmen, devrim sonrasında yapılan ilk özgür ve serbest seçimlerde Nahda büyük bir zafer kazandı ve siyaset sahnesine geri döndü. Nahda'nın bu başarısında Bin Ali'nin iktidardan düşmesiyle oluşan güç boşluğunun doldurulamaması ve Gannuşi'nin Ocak 2011'de ülkeye dönmesinden sonra partinin örgütlenmeyi gerçekleştirmesi ve oluşan boşluğu doldurması etkili oldu. Bkz: Esposito, Sonn ve Voll, s. 188-189.

“Tunus’ta nihai sonuçlar açıklandı”, Anadolu Ajansı, 27.10.2011.

50

“Tunus'ta koalisyon anlaşması”, Aljazeera Türk, 22.11.2011. 
alan selefilerle seküler kesim arasındaki gerginlik döneminde gerçekleşen siyasi suikastlar ülkedeki iç istikrarsızlığı daha da derinleştirdi. ${ }^{51}$ Nahda partisi iç istikrarsızlığ 1 aşmak için hükümetten çekilme kararı aldı ve teknokratlardan oluşan bir hükümetin kurulmasına razı oldu.

Rejim değişikliğine yönelik ikinci adım, Kurucu Meclis'in yeni anayasayı 27 Ocak 2014'te kabul etmesi oldu. Meclis Başkanı Mustafa Bin Cafer, anayasanın kabulünden sonra yaptığı açıklamada, "bu anayasa Tunusluların rüyası, devrimin yeniden canlanmasının bir kanıtı. Yeni anayasa, demokratik sivil bir ulus oluşturacak" diyerek bu geçişe vurgu yapt1. ${ }^{52}$ Anayasa üzerindeki bu uzlaşma Bin Ali'nin devrilmesinden sonra Tunus'un demokratik rejime geçişte çok önemli bir dönüm noktası oldu. Şükrü Hanioğlu'na göre, ${ }^{53}$ çatışma potansiyeli yükssek olan laik ve İslami kesim karşılaşılan sorunları aşmayı başardı. Bunu başarmalarının en önemli nedeni, tarafların önemli tavizler vermesi ve temel noktalar üzerinde çatışmak yerine insan hakları, katılımcı demokratik cumhuriyet, egemenliğin halka aidiyeti, hür seçimler, kuvvetler ayrılığı, hukukun üstünlüğü, kadın-erkek eşitliği gibi evrensel değerler üzerinde uzlaşmaya odaklanmalarıdır. Hanioğlu'na göre, tarafların uzlaşma noktaları yeni anayasaya da yansımıştır. Yeni anayasanın değiştirilemez ilk iki maddesi "Tunus'un bağımsız bir devlet olduğunu, dininin İslam olduğunu" vurgularken, aynı zamanda, onun "vatandaşlık, halk iradesi ve hukukun üstünlüğüne dayandığının" da vurgulamaktadır. Yine anayasanın 6. maddesi "devletin din ve kutsalları koruyacağını" belirtirken, diğer yandan da "camiler ve diğer ibadet mekanlarının tarafsızl1ğını" ve "tekfir"e izin verilmeyeceğini de hüküm altına almaktadır.

Ocak 2014'te yürürlüğe giren yeni anayasa seçilmiş bir cumhurbaşkanı, bir başbakan ve bir kabineden oluşan yarı başkanlık hükümet sistemini getirdi. ${ }^{54}$ Yeni anayasanın kabulü sonrasında 26 Ekim 2014'te yapılan ilk genel seçimde laik Nida Tunus partisi 217 üyeli parlamentoda 85 sandalye kazand1. En yakın rakibi Nahda partisi ise 69 sandalye kazandı. Sürecin devamında eski rejimle bağları bulunan ve 1981-1986 yılları arasında dışişle-

51 Esposito, Sonn ve Voll, s. 191-195; "Şükrü Belayid suikastı Tunus sokaklarını karıştırdı", BBC Türkçe, 06.02.2013; "Tunus: iki suikast, tek silah”, BBC Türkçe, 26.07.2013.

52 “Tunus'ta yeni anayasa yürürlüğe girdi”, Aljazeera Türk, 27.01.2014.

53 M. Şükrü Hanioğlu, “Tunus’tan alınacak ders”, Sabah, 09.02.2014.

54 “Tunus’ta cumhurbaşkanlığı yarışı”, Aljazeera Türk, 21.12.2014. 
ri bakanı, 1990-1991'de de meclis başkanı olarak görev yapmış olan Nida Tunus partisi lideri Beji Caid Essebsi, ikinci turu 21 Aralık 2014'te yapılan cumhurbaşkanlığı seçimini kazanarak Tunus'un yeni cumhurbaşkanı oldu. Nahda ise cumhurbaşkanlığı seçimlerinde aday göstermedi. Nahda lideri Gannuşi, "kutuplaşmanın derinleşmesini ve ülkenin bölünmesini önlemek istedikleri" için böyle bir politika benimsediklerini söyledi. ${ }^{55}$

2016 y1lı Nahda'nın dönüşüm yılı oldu. Mayıs 2016'da yapılan parti kongresinde konuşan Gannuşi, "davet ve siyaset" faaliyetlerini birbirinden kesin çizgilerle ayrıştıracaklarını ilan etti. Gannuşi'ye göre "modern bir devlet, ideolojilerle, büyük sloganlarla ve siyasi çekişmelerle değil, pratik programlarla idare edilir". ${ }^{56}$ Gannuşi, 2016 y1lında Foreign Affairs dergisine yazdığı makalede bu dönüşümü "siyasi İslam'dan Müslüman demokrasiye" geçiş şeklinde adlandırdı. Gannuşi’ye göre, Nahda artık kongrede resmileşen kararlara uygun olarak sosyal, eğitim, kültürel ve dini faaliyetlerde bulunmayacak, yalnızca siyasete odaklanacak. Bu alanlar partinin değil sivil toplumun bir alanı olmalıdır. Ona göre siyasi ve dini alan birbirinden ayrılmalıdır. Çünkü hiçbir siyasi parti dini temsil edemez veya etme iddiasında olmamalıdır. Dini alan bağımsız ve tarafsız kurumlar tarafindan yönetilmeli ve din tarafsız olmalıdır. Ona göre;

Nahda'nın, İslamcı bir hareket olarak değil, Müslüman demokrat bir parti olarak anlaşılması daha uygun düşmektedir. Biz, Tunuslulara dini konularda vaaz etmek yerine, onların günlük sorunlarına çözüm üretmeye çalişıyoruz. Açık olmak gerekirse, İslam'ın prensipleri her zaman Nahda'ya ilham kaynağı olmuştur ve değerlerimiz bize yol göstermeye devam edecektir. Ancak Nahda'nın (veya başka herhangi bir partinin) dini özgürlükler için mücadele etmesine artık gerek yoktur: Yeni anayasa uyarınca, tüm Tunuslular, inançlı, agnostik veya ateist olsalar da aynı haklara sahiptir. ${ }^{57}$

İslami hareketin partisi Nahda'nın dönüşüm politikası ve 1 lımlı tutumu Tunus'un demokratik rejime geçiş sürecinde belirleyici oldu. Nahda demokratik rejimin yerleşmesi için hem iktidardan feragat etti hem de anayasa yapım sürecinde kendi yaklaşımlarından tavizler verdi. Devrim öncesi

\footnotetext{
55 "Tunus'un yeni cumhurbaşkanı laik aday Es Sebsi”, BBC Türkçe, 22.12.2014; “Tunus'ta laik Nida Partisi resmen galip", BBC Türkçe, 30.10.2014.

56 Fatih Okumuş, "Nahda tecrübesi ve İslami hareketin geleceği”, Anadolu Ajansl, 17.06.2016.

57 Gannuşi, s. 63-64.
} 
dönemde rejim güvenliğine tehdit olarak görülen Nahda, devrim sonrası demokratik rejimin inşasında önemli derecede katkıda bulundu.

\section{Tunus Dış Politikası}

Tunus Fransız sömürgesi iken, 1956 yılında bağımsız bir devlet oldu. Bağımsızlıktan sonra Tunus dış politikası Burgiba rejiminin tercihlerine ve yeni devletin bağımsızlığını güçlendirme politikasına göre şekillendi. Tunus dış politikasını bu dönemde yönlendiren diğer hedef ekonomik kalkınma ve modernleşme çabalarına dış kaynak desteği bulmaktı. Rejimin dış politikadaki tercihi yeni devletin yönünü ve eksenini belirlerken, bağımsızlığı güçlendirme politikaları zaman zaman dış politika sorunlarına yol açt1.

Tunus bağımsızlık mücadelesini bir Batı devleti olan Fransa'ya karşı vermiş olmasına rağmen, dış politika tercihini Batı bloku yönünde yaptı. Burgiba, bağımsızlıktan hemen sonra yaptığı açıklamada Tunus'u kapitalist-liberal Batı ile özdeşleştirdiğini ve NATO üyeliği amaçladığını belirtti: "Ben tarafsızlığa karşıyım ve NATO'ya katılmanın çıkarımıza olduğunu düşünüyorum. Biz Batı ve özgür dünyanın ayrılmaz bir parçasıyız" ${ }^{58}$ Burgiba ayrıca sol eğilimli Arap milliyetçiliğinden farklı anlayışta olduklarını, bu nedenle Soğuk Savaş’ta Tunus'un kesin bir şekilde Batı'nın özgür dünyasını seçtiğini ve bu dünyanın rakip kampı olan Komünist dünyaya ait olmadıklarını açıkladı. ${ }^{59}$ Burgiba'nın Batı tercihi politikasıyla uyumlu olarak bağımsızlıktan hemen sonra Tunus, Fransa ile ilişkilerini geliştirme politikası izledi. Fransa ile ekonomik bağımlılık ilişkisi içinde olan Tunus, bu ilişkiyi sürdürmek ve özellikle ekonomik kalkınma için Fransa'dan ekonomik destek ve dış yatırım almaya çalıştı. ${ }^{60}$

58 Lotfi Ben Rejeb, "United States Policy towards Tunisia: What New Engagement after an Expendable 'Friendship'?", The Making of the Tunisian Revolution: Contexts, Architects, Prospects, Nouri Gana (ed.), Edinburgh: Edinburgh University Press 2013, s. $82-83$.

59 Rejeb, s. 83; Amy Aisen Kallander, "'Friends of Tunisia': French Economic and Diplomatic Support of Tunisian Authoritarianism", The Making of the Tunisian Revolution: Contexts, Architects, Prospects, Nouri Gana (ed.), Edinburgh: Edinburgh University Press 2013, s. 105.

60 Kallander, s.105. 
Tunus bir yandan Fransa ile ilişkilerini geliştirmeye çalışırken, diğer yandan ona karşı bağımsızlığını güçlendirmeye çalışıyordu. Bu politika Fransa ile sorunların yaşanmasına neden oldu. 1950'li yılların sonlarında Tunus, Fransa'ya karşı bağımsızlık mücadelesi veren Cezayir savaşçılarını destekleme politikası izledi. Ayrıca Tunus bağımsızlı̆̆ına aykırı olarak gördüğü topraklarındaki Fransız askeri üssünün boşaltılmasını istedi. Bu politikalar iki ülkeyi askeri çatışma noktasına getirdi. İki ülke arasında meydana gelen çatışma sonrasında Fransa 1963 yılında Tunus'taki askeri üssü boşaltmak zorunda kald $1 .{ }^{61}$ Fransa ile yaşanan sorunlardan dolayı Tunus, ABD'den destek alma çabasına girdi. Tunus'un bu yöndeki dış politikası başarılı oldu ve ABD, Tunus'u tanıyan ilk büyük devlet oldu. ${ }^{62}$ Tunus ayrıca Fransa'dan alamadığı askeri ve ekonomik desteği ABD'den almaya başladi. ${ }^{63}$

Tunus lideri Burgiba, 1960'lı yılların ortalarından itibaren iç politikada ekonomik sorunlardan kaynaklanan muhalefet hareketleriyle yüzleşti. Bu nedenle Burgiba Fransa ile ilişkilerini tekrar düzeltme çabası içine girdi. Özellikle 1970 ve 1980 'lerde Tunus'ta kötüleşen iç siyasi ortam ve çatışmalar, Libya ile yaşanan gerginlikler nedeniyle Burgiba, Fransız desteğine daha çok önem verdi. Bu çabalardan sonra iki ülkenin diplomatik, askeri ve ekonomik ilişkileri arttı. Burgiba 1960'larda uyguladığı sosyalist ekonomi politikalarını 1960'ların sonunda terk etti ve tekrar liberal ekonomi politikalarına yöneldi. Liberal ve dışa açık ekonomi politikası Tunus dış politikasına da yansıdı. Özellikle Fransa ile ekonomik ilişkiler arttı. ${ }^{64}$ İki ülke ticari ilişkilerinin geliştirilmesi için yeni mekanizmalar oluşturul-

${ }^{61}$ Ancak Burgiba, Fransa ile uzun dönem ilişkileri bozmak istemedi. Burgiba "bu bizim Fransa ile son kavgamızdır", "biz Fransa ile işbirliği yapacağız, birlikte az gelişmişliği yenmek için" diyerek iki ülke ilişkilerinin önemine vurgu yaptı. Bkz: Alexander, s. 130-132; Kallander, s. 105; s. 132.

62 Sarah Souli, “After Obama, what comes next for US-Tunisia ties?”, 28.09.2016, http:// www.al-monitor.com/pulse...

63 ABD ve Tunus 1957 'de ilk iki taraflı ekonomik ve teknik yardım anlaşması imzaladı. Bu kapsamda ABD, Uluslararası Kalkınma Ajansı (USAID) vasitasıyla 1994 yılına kadar Tunus'un ekonomik kalkınma programını destekledi. 1957-84 arasında USAID desteği Tunus'un gelirinin yaklaşık altmışta birini oluşturdu. Bu destek 1960'larda yaşanan Tunus-Fransa krizi sırasında artarak devam etti ve 1960-1969 yılları arasında ABD'nin Tunus'a yaptığı yiyecek yardımı 316 milyon doları buldu. Bkz: Alexander, s. 139.

64 Alexander, s.132. Kallander, s. 106. 
du. Fransa bu dönemde Tunus'un en büyük ticari ortağ1 oldu. Fransa'nın Tunus'a yaptığı yardım, dünyada bir ülkeden diğerine yapılan kişi başına düşen yardımların en yükseğine çıktı. Fransa ayrıca Tunus'un güvenliğinin birincil garantörü oldu. 1970'lerin başlarında Fransa, Tunus'a silah satış yasağını kaldırdı ve Tunus'un askeri ve iç güvenlik güçlerinin eğitimine katk1 sağlad1. ${ }^{65}$ Burgiba 1980'li yıllarda da Fransa'dan destek almaya devam etti. Bu destek ekonomik ve güvenlik desteğinin yanında siyasi desteği de içeriyordu. ${ }^{66}$ Özellikle 1979 İran devriminden sonra devrimin bölgeye yayılmasından endişelenen Batı ülkelerinin bölgedeki seküler rejimlere ve dolayısıyla Burgiba rejimine desteklerini artırmaları bu rejimlerin İslami hareketlere yönelik politikalarını güvenlikleştirmelerine ve sorunu uluslararasılaştırmalarına olanak sağladı.

1987 y1lında kansız bir darbeyle Burgiba'yı devirerek iktidara gelen Bin Ali döneminde Tunus dış politikasının temel tercihlerinde bir değişiklik olmadı. Bin Ali iktidara geldikten sonra Batı ile geleneksel ilişkileri sürdürme ve iktidar değişikliğine yönelik dış destek arayışına girdi. Bu kapsamda Bin Ali, ABD'den iktidar değişikliği için destek almaya çalıştı. ABD'nin yeni yönetimi desteklemesiyle iki ülke önceki yönetime göre daha fazla yakınlaştı ${ }^{67}$ Bin Ali aynı desteği Fransa'dan da aldı. 1988 yılında Fransa'y1 ziyaret eden Bin Ali, bu ziyarette Fransa ile ekonomik, kültürel ve askeri işbirliğini artırmaya odaklandı. Cumhurbaşkanı Mitterrand bu ziyaret s1rasında yaptığı açıklamada Bin Ali'yi "barış̧̧ıl bir geçişin ve demokratik yenileşmenin bir yaratıcısı" olarak tasvir ederek, onun darbeyle iktidara gelmesini meşrulaştırd1. ${ }^{68} 1990$ 'l 1 yıllarda Tunus diş politikası, komşu Cezayir'de başlayan iç savaş ${ }^{69}$ ve I. Körfez Savaşı etrafında şekillendi. Bin Ali, Cezayir'deki İslami hareketlerin ülkesine yayılmasını önlemek için iç politikada sert önlemler alırken, dış politikada da Fransa ve ABD'den destek arayışına girdi.

\footnotetext{
65 Alexander, s.132-133.

66 Kallander, s.107.

67 Alexander, s.139.

68 Kallander, s.108-109.

69 Cezayir'de 1990 ve 1991 'de yapılan seçimleri kazanan İslami cepheye karşı ordu yönetime el koydu ve seçimleri iptal ederek İslami cepheyi yasa dışı ilan etti. $\mathrm{Bu}$ gelişmeler ülkeyi iç savaşa sürüklemiş ve bu savaş 1990'l y yılların sonuna kadar devam etmiştir. Bkz: Levent Baştürk, "1992 Cezayir Darbesi: Rekabetçi Otoriter Rejimin Doğuşu”, Ortadoğu Analiz, 2016, Cilt 8, Say1 76, s. 58-60.
} 
"Anti-demokratik köktendincilere" karşı seküler rejimleri destekleme politikası uygulayan Batı ülkeleri bu dönemde Bin Ali’ye büyük destek verdi. Fransa Bin Ali'yi köktendinciliğin yayılmasına karşı bir siper olarak görüyordu. ${ }^{70}$ Tunus, Fransa'nın bu politikasından yararlanarak Fransa ile daha yoğun diplomatik ve güvenlik işbirliğine girdi. İki ülke 1991 yılında kültürel işbirliği ve finansal yardım anlaşması imzaladı. ${ }^{71}$ Fransa ayrıca Bin Ali'nin iç politikada İslamcılara karşı yürüttüğü sert politikaları görmezden geldi ve ekonomik yardımları artırdı. ${ }^{72} 11$ Eylül 2001 saldırılarından sonra Tunus Fransa ile diplomatik ve güvenlik ilişkilerini yoğunlaştırdı. Bin Ali ve Fransa dışişleri bakanı Hubert Vedrine, yaptıkları görüşme sonrasında "terörizmin bütün şekilleriyle mücadele edeceklerini ve bu amacı başarmak için istişarelerini yoğunlaştıracaklarını" ilan ettiler. Fransa Cumhurbaşkanı Jacques Chirac, Aral1k 2001'de Tunus'u ziyaret etti ve bu ziyarette iki ülkenin terörizm konusunda benzer görüşlere sahip olduğunu vurguladı. ${ }^{73} 11$ Eylül sonrasında Fransa' dan açık destek alan Bin Ali, Nicolas Sarkozy döneminde de bu desteği almayı sürdürdü. 2007 yılında Tunus'u ziyaret eden Sarkozy, ikili ilişkilerin önemine vurgu yaptı ve Fransa-Tunus ilişkilerini "çok güçlü dostluk" olarak tanımladı. ${ }^{74}$ Bölgesel istikrarsızlık hakkında paylaşılan endişeler, 1990'lar boyunca Tunus ve ABD arasındaki güvenlik işbirliğinin artmasına katkı sağladı. Bu kapsamda ABD ve Tunus bölgede askeri tatbikatlar yaptı. ${ }^{75} 11$ Eylül saldırıları sonrasında iki ülkenin güvenlik ilişkileri üst boyutlara çıktı. Bin Ali, 11 Eylül saldırılarından sonra ABD'nin benimsediği "teröre karşı savaş" politikasını destekledi. Bu destek kapsamında Tunus, ABD’ye Kuzey Afrika ve Avrupa'daki İslami hareketler hakkında istihbarat sağladı. Bin Ali ayrıca ABD'nin 2001 y1lında başlattığ 1 Afganistan operasyonunu destekledi. ABD de bu destek karşılığında Tunus'a yaptığı güvenlik ve istihbarat desteğini $\operatorname{artırd1} 1{ }^{76} \mathrm{Bu}$ destek ve yardımlar, Tunus rejiminin İslami hareketlere yönelik güvenlik politikalarıyla Batı ülkelerinin bölgeye ve Tunus'a yönelik politikalarının büyük ölçüde örtüşmesinden kaynaklandı. Bu durum otoriter rejimleri

70 Pia Christina Wood, "French Foreign Policy and Tunisia: Do Human Rights Matter?", Middle East Policy, 2002, Cilt 9, No 2, s. 92.

71 Kallander, s.110.

72 Alexander, s.133.

73 Wood, s.105-106.

74 Kallander, s.115.

75 Alexander, s.140-141.

76 Alexander, s. 140-141; Wood, 105. 
güçlendirirken, onların İslami hareketlere ve diğer muhalefet unsurlarına yönelik baskıcı tedbirlerini meşrulaştırmalarına katkı sağladı.

Devrim sonrası Tunus dış politikası, yeni rejime geçiş koşulları ve zorluklarıyla şekillendi. Troyka olarak bilinen ilk hükümetin dış politikası Arap dünyasına yayılan devrim dalgasından etkilendi. Eric Reidy'e göre, ${ }^{77}$ devrim sonrası ilk hükümetin dış politikası ideolojik düzeyde Arap dünyasında insan hakları, sivil özgürlükler ve demokrasinin desteklenmesine dayanıyordu. Bu nedenle Tunus Şubat 2012'de Suriye hükümeti ile ilişkilerini kesti. Cumhurbaşkanı Marzuki Ekim 2013'te Birleşmiş Milletler'de yaptığı konuşmada eski cumhurbaşkanı Muhammed Mursi'nin serbest bırakılması için Mısır'a çağnı yaptı. Tunus'un dış politikadaki yeni prensipleri onun bölgesel ittifaklarını da değiştirdi. Tunus devrim sonrasında Türkiye ve Katar'a daha yakın dururken, Suudi Arabistan ve Birleşik Arap Emirlikleri ile daha mesafeli ilişki içinde oldu. Cumhurbaşkanı Marzuki, Tunus dış politikasına yeni bir yön çizme arayışı kapsamında ayrıca Afrika ile yeni ilişkiler inşa etmeye, Orta ve Güney Amerika ve Doğu Asya ülkeleriyle ilişki kurmaya çalıştı.

Troyka hükümeti döneminde Tunus-Fransa ilişkileri gergindi. Fransa halk ayaklanması devam ederken Bin Ali rejimini destekleme politikası izlemişti. Fransa dışişleri bakanı Michele Alliot-Marie, gösteriler devam ederken yaptığı konuşmada Bin Ali'nin durumu kontrol altına alabilmesi için Tunus güvenlik güçlerini destekleyeceklerini söyledi. ${ }^{78}$ Devrimden sonra Fransa, Nahda'nın açık başarısına rağmen seküler partileri destekledi. Dönemin Fransa içişleri bakanı Manuel Valls yaptığı konuşmada, Müslüman Kardeşler ve Selefiler öncülüğünde kurulan "İslami faşist diktatörlük" nedeniyle Tunus'un Arap Baharı için bir model olmadığını söyledi. Ona göre, Müslüman Kardeşler ve Selefiler Tunus'ta hak ve özgürlükler için bir tehdit doğurmaktadır. Valls ayrıca, Fransa'nın buna göz yumamayacağı ve gericilere karşı seküler ve modernistleri destekleyeceğini açıkladı. Tunus bu dönemde Fransa'nın taleplerine aykırı dış politika kararları aldı. Tunus Fransa'nın Mali'ye müdahalesi sırasında dış müdahalelere karşı olduğunu açıklayarak hava sahasını açmayı reddetti. ${ }^{79}$

77 Eric Reidy, “Tunisia's new government shifts foreign policy”, 24.04.2015, http://www. al-monitor.com/pulse...

78 Stefan Simons, "Dumping Old Friends: France Makes Awkward U-Turn on Tunisia Policy”, 20.01.2011, http://www.spiegel.de/international...

79 Sami Brahem, "Let Tunisia Build a Democracy, Free from French Interference", 17.02.2013, https://www.theguardian.com/commentisfree... 
Ancak Tunus iç politikada İslamcılar ile sekülaristler arasında yaşanan gerginlikten kaynaklanan 2013 ve 2014 yılları arasında yoğunlaşan iç karışıklıklarla yüzleşti. Bu ortamda Ekim 2014'te yapılan genel seçimlerde laik Nida Tunus partisi birinci parti olurken, eski rejim döneminde dişişleri bakanlığ1 ve meclis başkanlığ görevlerinde bulunmuş Nida Tunus partisi lideri Beji Caid Essebsi, Aralık 2014'te yapılan cumhurbaşkanlığ seçimini kazanarak Tunus'un yeni cumhurbaşkanı oldu. Essebsi döneminde Tunus dış politikası da değişmeye başladı. Yeni hükümet ideolojik pozisyondan uzak daha pragmatik ve tarafsız dış politika izlemeye başladı. Bu dönemde Mısır'la daha yakın ilişkiler kuruldu. Tunus Türkiye ve Katar ile olan yakınlığını azaltırken, Suudi Arabistan ve Birleşik Arap Emirlikleri ile ilişkilerini geliştirdi. ${ }^{80}$ Bir önceki hükümet döneminde kötüleşen Fransa-Tunus ilişkileri Essebsi döneminde düzelmeye başladı. Cumhurbaşkanı Essebsi, Nisan 2015'te Fransa'yı ziyaret etti ve Fransa Cumhurbaşkanı Hollande'la bir önceki hükümet döneminde azalan Fransız yardımlarının yeniden artırılması konusunda görüşmeler yaptı. ${ }^{81}$

Devrim sonrası Tunus-ABD ilişkileri istikrarlı bir seyir izledi. ABD, Tunus'un yeni rejime geçiş sürecini destekledi. Tunus, ekonomik krizlerden korunmak için 2011'de ABD'den ek 1 milyar dolar yardım aldı. 2012'den sonra artmaya başlayan iç karışıklık nedeniyle Tunus ABD ile daha yoğun güvenlik işbirliğine girdi. Bu işbirliği terörle mücadele, istihbarat sağlama ve sınırların daha güvenli hale getirilmesi konularını içeriyordu. Başkan Barack Obama 2015 yılında yaptığı konuşmada ABD ve Tunus'un yakın ittifak ilişkisi kuracaklarını belirtti. Bu kapsamda, Kasım 2015'te ABD-Tunus Ortak Ekonomik Komisyon oluşturuldu. Bu komisyonla iki ülke arasında stratejik diyalog ve ortak askeri işbirliği geliştirme amaçlandı. Tunus 2016 yılında ABD'den 150 milyon dolar hibe ve kredi desteği ald1. ${ }^{82}$ ABD'nin Tunus'taki 1lımlı Nahda partisi öncülügün̈de kurulan hükümeti desteklemesi ülkedeki ve bölgedeki aşırı hareketlere karşı geliştirdiği politikasına dayanıyordu. Bu destek demokratik geçiş sürecindeki Tunus'un iç istikrarına da katkı yaptı.

\footnotetext{
80 Reidy, a.g.e.

81 Alexander, s.134.

82 Vish Sakthivel, "Taking Stock of U.S. Policy Options in Algeria, Morocco, and Tunisia”, 09.09.2016, https://www.fpri.org/article...; Souli, "After Obama, what comes next for US-Tunisia ties?", 28.09.2016.
} 


\section{Sonuç Yerine: Tunus Dış Politikası Analizi}

Önceki bölümlerde Tunus rejiminin yapısı, işleyişi ve rejimin güvenliğine tehdit olarak algıladığı İslami hareketin ortaya çıkışı, gelişimi ve dönüşümü ile Tunus dış politika davranışları incelendi. Bu inceleme bize rejim güvenliği ile Tunus dış politikası arasındaki ilişkiyi analiz etme imkânını sunmaktadır. Bu bölümde örnek olay incelemesini dönemselleştirerek bağımlı ve bağımsız değişken arasındaki ilişki değerlendirilecektir.

\subsection{6-1987 Dönemi}

Tunus bir Fransız sömürgesi iken 1956 yılında bağımsız bir ülke oldu. Tunus'un bağımsızlığında büyük rol oynayan Burgiba, Fransa'da eğitim almış seküler, Batıcı ve modernist fikirlere sahip bir liderdi. Burgiba bu fikirlerle modern bir devlet ve toplum oluşturmak istiyordu. Burgiba ve elitinin tasarladığı Tunus rejimi ideolojik düzeyde Batıcı, modernist ve seküler; yöntem düzeyinde tek parti hâkimiyeti ve ömür boyu başkanlık sitemiyle otoriter; eylem düzeyinde yukarıdan aşağıya devrimci bir yap1 olarak ortaya çıtı.

Bağımsızlıktan sonra Tunus dış politikası yeni rejimin Batı tipi ve Fransa'yı model alan modernleşme hedefleri etrafında şekillendi. Bu kapsamda Tunus, dış politikada Batı eksenini tercih etti. Burgiba bağımsızlığın ilk yıllarında $\mathrm{ABD}$ ve Fransa ile ilişkilerini geliştirmeye ve bu ülkelerden siyasi ve ekonomik destek almaya çalıştı. Burgiba'nın Batı tercihi özellikle ABD'den destek almasını kolaylaştırdı ve alınan destek uluslararası alanda yeni rejimi güçlendiren bir etki yaptı. Rejimi güçlendiren Burgiba, 1950'lerin sonundan 1960'ların ortalarına kadar Fransa'ya karşı bağımsızlığı güçlendirmek için meydan okuyucu diş politika izledi. Bu politika kapsamda Fransa'nın Tunus'taki askeri üssünü kapattırmak için, Fransa ile askeri çatışmaya girdi ve üssü kapattırmayı başardı. Burgiba ayrıca Fransa'ya karşı ekonomik yönünde adımlar attı ve Fransa'nın Tunus'taki ekonomik varlıklarını millileştirdi.

Burgiba rejimi, 1960'l y ylların ortalarından itibaren ekonomik politikaların başarısızlığından kaynaklanan sol ve sendikalardan gelen toplumsal muhalefet dalgasıyla yüzleşti. Bu durum karşısında Burgiba, Fransa'ya karşı uyumlu bir dış politika izlemeye başladı ve Fransa ile ilişkilerini düzeltme 
çabalarına girişti. Bu çabaların içinde ekonomide liberal politikalar izleme, özelleştirme yoluyla Fransız yatırımlarına imkân sağlama gibi açılımlar vardı. Bu çabalar sonucunda iki ülke ilişkileri 1960'lı yılların sonlarından itibaren düzelmeye başladı. Fransa, daha önce askıya aldığı ekonomik ve güvenlik yardımlarını tekrar başlattı. ABD bu dönemde rejime yönelik sol kesimden gelen muhalefete karşı Tunus'un Doğu blokuna kayma endişesi nedeniyle rejime yönelik desteğini artırdı.

Burgiba rejimi, 1970 ve 1980 'lerde de rejim güvenliğini tehdit eden iç muhalefet hareketleriyle yüzleşti. 1970'li yılların ortalarından itibaren artan ekonomik sorunlar kitlesel grevlere ve istikrarsızlıklara yol açtı. $\mathrm{Bu}$ toplumsal sorunlar Tunus'taki İslami hareketi dönüştüren ve güçlendiren bir etki yaptı. Bu döneme kadar modernleşme politikalarına karşı dini kimliği koruma çabalarına odaklanan İslami hareket, bu dönemden sonra toplumsal sorunlarla ilgilenmeye ve siyasallaşmaya başladı. Ayrıca 1979 yılında gerçekleşen İran devrimi de bölgedeki İslami hareketleri derinden etkiledi. Tunus İslami hareketi bu dönemde örgütlenme düzeyini artırarak partileşme yolunda adımlar attı. Burgiba İslami hareketin güçlenmesini rejimin güvenliğine tehdit olarak algıladı. Burgiba İslami hareketi dengelemek için, dış ittifak arayışına girdi. Bu dönemde ABD ve Fransa, İran devriminden sonra teokratik rejimlerin yayılacağı endişesiyle Tunus rejimini İslami harekete karşı destekleme politikası izledi. Burgiba aldığı dış destekle rejime tehdit olarak gördüğü İslami hareketi İran'la işbirliği yapmakla suçlayarak, harekete karşı baskıcı ve sert tedbirler aldı. O, bu şekilde yaparak dış ittifak yoluyla rejim güvenliğine yönelen iç tehditleri dengeleme yoluna gitmiş oldu.

\subsection{7-2011 Dönemi}

Burgiba'yı kansız bir darbeyle devirerek iktidarı ele alan Bin Ali, rejim değişikliğinden ziyade rejimi güçlendirme ve Burgiba'nın mirasını devam ettirme politikası izledi. Bin Ali 1990'lı yılların başlarına kadar Burgiba döneminde yıpranan rejimi güçlendirmek için siyasi liberalleşme politikaları izledi. Çoğunluğunu İslamcıların oluşturduğu siyasi mahkumları affetti. Ülkedeki tüm kesimleri ulusal sözleşme tartışması etrafında toplayarak rejimin kapsayıcılığını ve meşruiyetini artırdı. Bin Ali dış politikada bu kapsamda adımlar attı. O iktidara gelir gelmez Tunus'un Batı tercihinde 
bir değişme olmadığını deklare etti. Ayrıca Fransa ve ABD'den iktidar değişiminin gerekliliği yönünde destek almaya çalıştı.

İç politikada İslami hareketin partisi Nahda'nın güçlenmesi ve 1989 y1lında yapılan genel seçimlerde göstererek iktidar partisinin en güçlü rakibi haline gelmesinden sonra Bin Ali, Nahda'yı rejim güvenliğine tehdit olarak görmeye başladı. Bu dönemden sonra Tunus dış politikası da rejim güvenliğine yönelik iç tehditlere göre şekillendi. Bin Ali iç tehdit olarak algıladığı İslami hareketi dengelemek için dış destek almayı amaçladı ve 1990'lı yılların başlarında başlayan Cezayir'deki İslamcılarla laik kesim arasındaki iç savaşın yayılması endişesini dış destek almak için kulland. Bin Ali bu dönemde İslami hareketle mücadele stratejisi olarak tehdidi uluslararasılaştırma stratejisi izledi. ABD ve Fransa gibi Batılı ülkeler bu dönemde İslamcı hareketlerin yayılmasını engellemek için Bin Ali rejimine büyük destek verdiler. Bu ülkeler Bin Ali rejimini, İslamcı hareketlerin yayılmasına karşı bir siper olarak görmeye başladılar ve bu kapsamda Tunus'a yönelik ekonomik ve güvenlik yardımlarını artırdılar. Aldığı bu dış destekle Bin Ali, İslami harekete ve diğer muhalif unsurlara karşı sert ve baskıcı politika izlemeye başladı. Özellikle İslami hareketi yok etmeye çalıştı. Rejimin bu sert tedbirlerle İslami hareketi büyük oranda baskılad1 ve onun gücünü azalttı. ABD ve Fransa, Bin Ali'nin içerde uyguladığ baskıcı ve İslami hareketleri yok etme politikalarına göz yumarak, rejimin güçlenmesine ve uluslararası meşruiyetini artırmasına katkı yaptı.

Bin Ali'nin rejim güvenliğini artırmak için içerde uyguladığı baskı, muhalefeti ve özellikle İslami hareketleri yok etme politikaları, yolsuzluklar, artan ekonomik problemler ve işsizlik rejimin sonunu getiren gelişmeler oldu. Aralık 2010'da ekonomik sorunlardan dolayı başlayan gösteriler, zamanla rejime yönelik halk ayaklanmasına dönüştü. 1956 yılında Burgiba tarafindan kurulan ve 1987 yılından sonra Bin Ali tarafindan devam ettirilen rejim, halk ayaklanmaları sonucu Bin Ali'nin 14 Ocak 2011'de ülkeden ayrılmasıyla sona ermiş oldu. Böylece Bin Ali'nin diş ittifak stratejisiyle iç rakiplerine dengeleme ve rejim güvenliğini sağlama politikası başarısız oldu. 


\subsection{1-2016 Dönemi}

$\mathrm{Bu}$ dönemde Tunus dış politikası yeni ve demokratik rejime geçiş koşulları tarafından şekillendirildi. Devrimden sonra yapılan ilk seçimde, 1 lımlı İslamcı Nahda partisi büyük bir başarı göstererek birinci parti oldu. Nahda öncülügünde kurulan koalisyon hükümeti döneminde Tunus dış politikası yeni rejimi ortaya çıartan koşullara uygun olarak ideolojik düzeyde demokrasi ve insan haklarının yayılması ekseninde şekillendi. Tunus izlediği dış politika çizgisine uygun olarak Türkiye ve Katar ile ilişkilerini geliştirdi. Tunus ayrıca Suriye ile ilişkilerini kesti ve devrik lider Mursi'nin serbest bırakılması için Mısır'a çağrı yaptı. Tunus'un yeni dış politikası, Fransa ile ilişkilerini de olumsuz etkiledi. Tunus bu dönemde Fransa'ya karşı yumuşak dengeleme politikası izlemeye başladı. Tunus Fransa'nın Mali'ye yaptığı askeri müdahaleye karşı çıktı ve müdahale sırasında hava sahasının kullanılmasına izin vermedi.

Tunus, 2013-2014 yılarında yoğunlaşan seküler muhalefet ve İslamcılar arasında yaşanan gerginlik ve iç istikrar sorunlarıyla yüzleşti. Bu ortamda 2014 yılının sonlarında yapılan genel seçimlerde seküler Nida Tunus partisi birinci parti oldu. Yine aynı yıl yapılan cumhurbaşkanlığı seçimini, eski rejimle bağları bulunan Nida Tunus partisi lideri Essebsi kazandı. Essebsi döneminde Tunus dış politikası demokrasi ve insan hakları yanlısı dış politikadan daha pragmatik ve Batı yanlısı bir dış politikaya dönüş yaptı. Bu kapsamda Tunus Mısır, Suudi Arabistan ve Birleşik Arap Emirlikleri ile ilişkilerini geliştirirken Türkiye ve Katar çizgisinden uzaklaştı. Yeni hükümet Fransa'ya karşı uyumlu bir dış politika izlemeye başladı ve Fransa ile ilişkilerini düzeltmeye çalıştı.

Sonuç olarak, 1956-2016 arası Tunus dış politikası esas itibariyle rejimin yapısı, rejim güvenliğine yönelik iç tehdit algılamaları tarafından şekillendirildi. Seküler ve Batı yanlısı modernleşme fikirlerini uygulamak için otoriter tek parti yönetimi şeklinde tasarlanan rejim, dış politikada bu amaçlara uygun tercihler yaptı. Bu şekilde yapılandırılan rejim, kendisine yönelik iç tehditler ortaya çıktığında bu tehditleri dengelemek için ise dış destek arayışına girdi. 2011 rejim değişikliği Tunus dış politikasını da değiştirdi. Ancak 2014 yılı sonunda eski rejimle bağlantılı seküler yönetimin iktidara gelmesiyle Tunus dış politikasının yönü tekrar değişti ve eski rejim çizgisine yaklaştı. Dolayısıyla Tunus örnek olayı rejim güvenliği ile dış politika davranışları arasında ilişkinin varlığını desteklemektedir. 


\section{Kaynakça}

Amy Aisen Kallander, "Friends of Tunisia': French Economic and Diplomatic Support of Tunisian Authoritarianism", The Making of the Tunisian Revolution: Contexts, Architects, Prospects, Nouri Gana (ed.), Edinburgh: Edinburgh University Press 2013, s. 103-124.

Christopher Alexander, Tunisia: Stability and Reform in the Modern Maghreb, London: Routledge 2016.

Curtis R. Ryan, Regime Security and Jordanian Foreign Policy, Gainesville: University Press of Florida 2009.

Emma C. Murphy, Economic and Political Change in Tunisia: From Bourguiba to Ben Ali, London: Macmillan 1999.

Eric A. Miller ve Arkady Toritsyn, "Bringing the Leader Back In: Internal Threats and Alignment Theory in the Commonwealth of Independent States", Security Studies, 2005, Cilt 14, No 2, s. 325-363.

Eric Reidy, “Tunisia's new government shifts foreign policy”, 24.04.2015, http://www.al-monitor.com/pulse...

Fatih Okumuş, "Nahda tecrübesi ve İslami hareketin geleceği”, Anadolu Ajansl, 17.06.2016.

H. Rumeysa Dursun, “Tunus'ta Otoriter Yönetim ve İslamcı Hareketin Doğuşu: Burgiba Dönemi Üzerine Bir Değerlendirme (1956-1987)”, Türkiye Ortadoğu Çalışmaları Dergisi, 2017, Cilt 4, Sayı 1, s. 132-157.

John L. Esposito, Tamara Sonn ve John O. Voll, Islam and Democracy after the Arab Spring, Oxford: Oxford University Press 2016.

Kenneth Perkins, "Playing the Islamic Card: The Use and Abuse of Religion in Tunisian Politics", The Making of the Tunisian Revolution: Contexts, Architects, Prospects, Nouri Gana (ed.), Edinburgh: Edinburgh University Press 2013, s. 58-80.

Levent Baştürk, "1992 Cezayir Darbesi: Rekabetçi Otoriter Rejimin Doğuşu”, Ortadoğu Analiz, 2016, Cilt 8, Say1 76, s. 58-60.

Lotfi Ben Rejeb, "United States Policy towards Tunisia: What New Engagement after an Expendable 'Friendship'?", The Making of the Tunisian Revolution: Contexts, Architects, Prospects, Nouri Gana (ed.), Edinburgh: Edinburgh University Press 2013, s. 81-102. 
M. Şükrü Hanioğlu, “Tunus’tan alınacak ders”, Sabah, 09.02.2014.

Marion Boulby, "The Islamic Challenge: Tunisia since Independence", Third World Quarterly, 1988, Cilt 10, No 2, s. 590-614.

Michael N. Barnett ve Jack S. Levy, "Domestic Sources of Alliances and Alignments: The Case of Egypt, 1962-73" International Organization, 1991, Cilt 45, No 3, s. 369-395.

Pia Christina Wood, "French Foreign Policy and Tunisia: Do Human Rights Matter?", Middle East Policy, 2002, Cilt 9, No 2, s. 92-110.

Randall L. Schweller, "Unanswered Threats: A Neoclassical Realist Theory of Underbalancing", International Security, 2004, Cilt 29, No 2, s. 159-201.

Raşid Gannuşi, "From Political Islam to Muslim Democracy: The Ennahda Party and the Future of Tunisia" Foreign Affairs, September/October 2016, s. 58-67.

Raşid Gannuşi, Laiklik ve Sivil Toplum, İstanbul: Mana Yayınları 2015.

Richard J. Harknett ve Jeffrey A. Vandenberg, “Alingment Theory and Interrelated Therats: Jordan and the Persian Gulf Crisis", Security Studies, 1997, Cilt 6, No 3, s. 112-153.

Richard Jackson, "Violent Internal Conflict and the African State: Towards a Framework of Analysis", Journal of Contemporary African Studies, 2002, Cilt 20, No.1, s. 29-52.

Rory McCarthy, "Re-thinking secularism in post-independence Tunisia" Journal of North African Studies, 2014, Cilt 9, No 5, s. 733-750.

Sami Brahem, "Let Tunisia Build a Democracy, Free from French Interference", 17.02.2013, https://www.theguardian.com/commentisfree...

Sarah Souli, "After Obama, what comes next for US-Tunisia ties?", 28.09.2016, http://www.al-monitor.com/pulse...

Stefan Simons, "Dumping Old Friends: France Makes Awkward U-Turn on Tunisia Policy", 20.01.2011, http://www.spiegel.de/international...

Steven R. David, "Explaining Third World Alignment," World Politics, 1991, Cilt 43, No 2, s. 233-256. 
"Şükrü Belayid suikastı Tunus sokaklarını karıştırdı", BBC Türkçe, 06.02.2013.

“Tunus: iki suikast, tek silah", BBC Türkçe, 26.07.2013.

“Tunus’ta cumhurbaşkanlığı yarışı”, Aljazeera Türk, 21.12.2014.

"Tunus'un yeni cumhurbaşkanı laik aday Es Sebsi”, BBC Türkçe, 22.12.2014.

“Tunus’ta koalisyon anlaşması”, Aljazeera Türk, 22.11.2011.

“Tunus'ta laik Nida Partisi resmen galip”, BBC Türkçe, 30.10.2014.

“Tunus'ta nihai sonuçlar açıklandı”, Anadolu Ajansı, 27.10.2011.

“Tunus’ta yeni anayasa yürürlüğe girdi”, Aljazeera Türk, 27.01.2014.

Veysel Ayhan, "Tunus İsyanı: Arapların Devrim Ateşini Yakması", Ortadoğu Etütleri, 2012, Cilt 3, No 2, s. 59-93.

Vish Sakthivel, "Taking Stock of U.S. Policy Options in Algeria, Morocco, and Tunisia", 09.09.2016, https://www.fpri.org/article... 